Pakistan Journal of Humanities and Social Sciences

January - March 2018, Volume 6, No. 1, Pages 1 - 16

\title{
The Role of Operational Risk Management in Performance of Banking Sector: A Study on Conventional \& Islamic Banks of Pakistan
}

\author{
Muhammad Yasran Rasheed ${ }^{1}$, Asif Saeed ${ }^{2}$, Ammar Ali Gull ${ }^{3}$ \\ ${ }^{1}$ MBA/ MS (Banking and Finance), GC University Faisalabad, Pakistan \\ Email: m.yasran@yahoo.com (Corresponding Author) \\ ${ }^{2}$ Doctorant, Institut de Recherche en Gestion (IRG), University of Paris-Est Creteil (UPEC) \\ France \\ ${ }^{3}$ Doctrant, Groupe de Analyse des Itinéraires et des Niveaux Salariaux (GAINS), Université \\ de Maine, France
}

\begin{abstract}
Operational risk has a great impact on the functions of financial institutions. As the complexity and size of firms in increasing, it also enhancing the operations risk in more harmful ways. If a firm is not able to perform its operational activities properly, then it is not possible for banks to get high profitability ratio. Firstly, the operational risk has not achieved the greater importance but with the passage of times all financial institutions have come to know that it is very important for all institutions to cover up the rate of risk in financial operations. By selecting 15 banks (Islamic \& Commercial Banks) from the year 2007 to 2011 focused on the internal factors of the banks which are mostly affected by the operational risk. Regression and correlation methods are used to evaluate the impact of Return on Asset, Debt/Equity Ratio, Spread Ratio, Capital Ratio and Asset management on the Return on Equity. The empirical results are shown that the awareness regarding operations risk has greater impact on the management of operational risk. Results are also shown that the operational risk disclosure also vary among different banks.
\end{abstract}

Keywords: $\quad$ Operational Risk, Performance, Islamic Banks, Conventional Banks

\section{Introduction}

Operational Risk belongs to risk of loss which resultantly occurred due to insufficient control or failure of inside processes, system and people or form external factors. It's predominantly associated with human errors, failure of internally operational strategies and inappropriate practices and controls. Such risk of losses formulated from the potential that breaches in internal controls, ineffective information systems, and fraudulent activities by failure of technology, unforeseen catastrophes or other operational and reputational problems. 
Operational risk always be found in all financial activities and products which basically offered by a financial institution.

The core theme of operational management is similar to market, liquidity and credit risks, which finds out exposure of operational risk of financial institutions; to comprehend what drives it, to allocate capital against it and distinguish trends internally and externally that would help to predicting it. Practices related prevention \& managing has always been significant for banks to maintain integrity of internal controls, preclude frauds and reduction of human error in transactions and so on. An effective operational risk management deals with definitive culpability to managing operational risk respites with the board, and risk level an organization receives, together with the basis for dealing such risks, is driven from top down by that kind of charged with ultimate responsibility for formulating the business.

Risk Management is vigorous part of any organization's strategic plan. It's like ongoing process of risk assessment via different gears, means and methods which explored all risks possibly faced by a firm, determine which are crucial to handle rapidly and implement organizational strategies which deals to that risks (Khan \& Habib, 2001). Risk is an environmental factor in which every organization performing their operations. No business can perform without lying risks (Shafiq \& Nasar, 2010). More risk taking means more profits generation. Without involving risk factor in business, growth becomes like nightmare (Asim, Khan \& Nazir, 2012).

Banks likewise other businesses also faced different kind of risks according to their operational activities. Every Bank's main objective is to providing financial services while managing operational risk and profit generation for its shareholders (Alimshan, 2011). Commonly there are two major types of bank which are performing their operations in Pakistan. First, which performing his activities by providing interest based loaning and deposits known as Conventional banks and $2^{\text {nd }}$ are Islamic Banks which provides services like deposits and loaning on the basses of Islamic law's principals.

Operational risk is a type of risk which arises from execution of business functions of a company. Operational risk has not received the same level of attention as credit risk and market risk have been received. Globalization increase, frequent changes in financial market, deregulations and corporate restructuring had a great impact on the banks operational functions. From failed and inadequate internal process, systems, people and external events, risk of direct and indirect loss result in companies. Legal risk is recognized as the subset of operations risk. Due to globalization and deregulation of financial services with increase in 
financial technology and development of new businesses had created great amount of operational risk for all banks and financial institutions. These developments have also making the risk profile and bank's activities more complex.

Numerous empirical researches have been made to cover-up all aspects of operational risks likewise definitional issues, its causes and effects on operational activates, management approaches, measurement models and evaluation of regulatory charge methods etc. (Hussain \& shafi, 2014). All financial institutions have also come to know that efficient and complete operational risk management can help them to achieve the aims and objectives the organizations. There are many approaches with the help of which board of directors can judge the operational risk that their organizing is facing. But it does not provide the proper information about the operational risks. Recently, operational risk management has attracted more attention because of huge losses which are incurred by a number of financial institutions. Privatization, globalization and deregulation processes increased the competitive pressures and financial companies experienced great operational losses from all over the world.

Operational risk has received wide-spread of recognition in 1995 due to failure of U.K's oldest financial institution. Some studies have been reminded that the inevitable extreme. It is very compulsory for banks develop approaches to measure the operational risk exposures and also manage these exposures. All banks mostly relied on risk management, auditors, internal process, insurance protections and control functions to manage the operational risk in institutes. These methods have great importance, but due to an increase in complexity of banking industry and extreme losses publicized from recent years needs more accurate and prudent operational risk management.

Operational risk was started to measure from 1998. Due to increase in complexity of financial institutions and in their operations, operational risk also started to increase. In early age of financial industry, organizations did not focused on risk related to operations of their organizations. But now, these days it has gained the popularity in all financial institutions. Moreover, purpose of current study is to give an overview of bank practices related to operational risk reporting in banking industry. As well aim of the study is to focus on the determinants of operational risk in banks which enables the banks to focus on the operational risk. Study's data based on 15 banks which are comprises both Islamic and commercial banks from the period of 2007 to 2011 for investigating the impact of operational risk in banking 
industry. This provides grounds to banks for determine the factors which are affected by the operational risk.

\section{A. Discussion}

Bank's focus on operational risk becomes mandatory because it cascades in all operations of a bank. Financial sectors are considered as backbone of the every economy in growth and developments. Banks are the mainly sources of financing to all businesses. According to Hussain, Ihsan and jawad (2016) last decade has experienced a lot of changes in management of the Banking sector, because largely bankruptcies in baking industry had shown like Lehman-Brothers and Bear Stearns. Pakistani Banking industry is avoiding such activities which involves huge factor of risk. In Pakistan banks follow the BASEL standards for capital adequacy ratio. Such standards require a minimum amount of capital truly maintained as minimum capital requirements. BASEL standards help out to banks for using as catalyst in credit decision and further postulate the effective risk management for banks to make them more competitive. A strongest operational risk management process leads to minimize the exposure of risk as well it can enhance the competitive ability of banks (Iqbal \& Mirakhor, 2011).

In Pakistan banking industry has encounter different kind of risks, like liquidity, credit, foreign exchange, interest rate, market risk and operational risk due to unstable and volatile environment in country (Shafiq \& Nasar, 2010). But the operational risk is the main focusing risk for the Banks in today's environment. It's most difficult to anticipate and in results, its unexpected appearance mostly leads to decline in market value as well affect the reputations of financial institutions (Lewis, 2004). If operational risk not be managed efficiently, it can be damaged heavily to any financial institution. While managing the operational risk, failure to managing can led to demise of numerous intuitions, since operational risk causes other firm-wide risks to be extreme (sweeting, 2011). Operational losses also covers some sort of failure, such losses also attracts media despite the fact that there's may be small kind of financial lose exists. Increased attention on operational losses causes to threats to institution's reputations (Sturm, 2013).

Therefore, above mentioned studies shows the significance of operational risks which is most dangerous risk for financial institutions. Because, if can't be managed timely \& efficiently resultantly it will damage financial institution's reputation in market as well in comparative environment (Ferreira, Viljeon \& Vuuren, 2016). Here, we tried to explore in which extant operational risk is dangerous to Banks in Pakistan both Islamic and commercial 
banks and what's kinds of measures have to take to manage such losses which can be takeover by operational risk management. The key questions are as under for being present study has been made.

i. How the internal factors are cause of operational risk in baking industry?

ii. How the profitability of banks is affected due to operational risk?

iii. How operational risk affects the debt and equity ratio of the organization?

\section{Literature Review}

Helbok and Wagner (2006) worked on the determinants of operational risk reporting in banking industry. Their study includes finding vital significance of risk management for banks, enhancement of market discipline by adoption of satisfactory reporting measures and for the trustworthiness of banking system. This paper was based on investigation of operational risk disclosure practice for the time frame of 1998 to 2001. The dependent variable is Operational risk disclosure. They used simple descriptive statistics and an econometric model, variable model and ordered logit model. They conclude his research by managing the risk spectrum of financial institutions which predominantly concealed credit \& market risks where universally probable demarcation of operational risk didn't exists.

Moreover, Modove and Berg-Yuen (2001) studied on Banking capital and operational risks and comparative analysis of regulatory approaches for a bank. They observed unpredicted events that could potentially cause the suddenly fall down for the entire bank. To apprehend the relationship between economic and regulatory operational risk capital they firstly examine the selected largely formatted internationally active banks. The dependent variables are Capital BIA and Capital LDA. Independent variables are gross income. They used Basic indicator approach like as Loss distribution approach and Extreme risk capital model. They propose that banks use Extreme risk capital model to determine a baseline or Capital allocation. They have found ECRM for decision making at top level of banks which have need of holistic and an integrated view of bank's extreme operational risk.

Furthermore, Mehra (2012) researched on Operational risk management in Indian banks and impact of ownership and size on range of practices for implementation of advanced measurement of operational risk essential for achievement of advance measurement approach. They used Rotated component Matrix. Chi. Square model and Cronbach Alpha model. They conclude that after sub-prime crisis Indian banks should have learning capability for regular basis bring up-to-date of self-assessment and scenario analysis results. 
Likewise, Acharyya (2008) also has done his contribution for gathering flawed evidence in regards managing operational risk from filed. His study belonged to check formulated strategies for prevention of operational damages in that sector which provides insurance services. While operational risk is not freshly threat to insurance providing institutions, to meet regulatory requirements companies maintain risk capital for any operational damage. They have selected the variables, damages to physical assets, external and in-house fraud, business distraction, process management and failure of system's execution of delivery. Since there's no opportunity in operational risk, other parties' involvement in operational risk market based trading activities have no benefit for business.

Similarly, Medova (2001) had worked to find integr point of operational risk and capital allocation for risk management which became intensive discussion and vibrant topics in the financial service industry because new Basel Accord proposal is now required from internationally active banks to set aside capital against these risks. She used credit risk model and POT model. The variables in this paper are macroeconomic variables and random variables (losses). She concluded that the risk capital framework proposed here allows quantification of operational risk losses based on an integrated view of risk. Furthermore, she had founded philosophy chart which presents high level controls and estimation of required excess capital requirements by using annually fixed unexpected level of extreme damages exceeding.

Jobst (2007) had conducted his research on constraints of consistent operational risk measurement and regulation, data collection and loss reporting. He worked that, rapid increase in size and complexities of banking industry have most opportunity to transpire in more distressing ways than several other sources of risk. He also scrutinized innumerable modeling constraints, consistent risk estimation and critical issues of coherent. Their findings divulge that effective operational risk dimension hinges on how the reporting of model sensitivity of quantitative method and operational risk losses effect the generation of reliable risk estimates.

Consideration and consequences on operational risk capital changes for banks was founded by Sundmacherin (2004). Study based on to isolate and discovers problems occurred in results by embracing Basel committee's recommendation related to measuring and manning operational risk. He used three sophisticated measurement methodologies for the calculation of operational risk capital charge. He concluded that the financial institutions benefit of using a more sophisticated approach would be potentially lower capital charge. 
Miranda, Berg and M. Leipoidt (2006) worked on data scanning for operational risk modeling. He defined operational risk as inadequate control, failure of internal process, systems and people or from external events. Study described proposing a scaling mechanism provides technique to sidestep the problem of data availability which enables an organization by putting clustered data originated from several units and each unit have his own special characteristics like exposure and size towards the operational risk. He showed the results of an investigation of relationship between the aggregate loss and an indicator of size explored towards the OR that financial institution.

Similarly, Jobst in February (2007) used new BASEL framework for control measures and treatment of operational risk. His findings shows regulations of international banking not moving to rigid controls towards risk based capital guidelines and market discipline have given more attentions to Operational Risk Management. He said that quantitative concepts, similar to those used to measure credit and market facing risks, is of particular in measuring operational risk. He used quantitative methodology and worked on internal data, external data. He made scenario analysis and also work on business environment and internal control factors. The variables in this paper were GDP and GEV. He used Peak-over Threshold method.

Izhar (2011) published his paper and identified operational risk exposure in Islamic banking. He explained operational risk management of financial organizations has undeniably attracted more attention from the practitioners and academics also the regulators over the last time-span. Earlier discussion of present research was on the history including origin and nature of Islamic banking and difference between conventional and non- conventional banking which provides info; conventional banking system is diverse to Islamic banking system by operational aspects. Further he had written Islamic banks are deal with fiduciary risks which arises form abandon misconduct and rupture of their investments. He concludes that hazardous type of risk which can subsidize significant losses to financial institution namely formatted as operational risk.

Laviada, Garcia and Rodriguez (2005) explored in which circumstances BASEL II behave with Spanish financial services sector. They had shown new regulatory and management requirements emerging the new vision of Operational Risk Management. By using Economic Capital Methodology he obtained main results from questioners and shown how Spanish financial system made sufficient efforts in operational risk management. They conclude that all institutions without exception would follow this process although Basel 
finally decided not to demand capital for this risk, since its correct management has been found to be necessary for the good functioning of any institution. "Consistency of risk reporting in financial services firms" a study conducted by Sundmecher (2006). He examined international banks operational risk disclosure's nature, the uniformity of disclosures, and their practicality. He used 75 financial institution's data from their annual reports of 2004 and 2005. He used VAR-methodology for measuring risk. Findings of the study had shown operational risk's disclosures differ significantly among the institutions in quality and quantity.

\section{Methodology}

Methodology is a set of practices use to solve a problem. Methodology is a series of options which gave us choices about that data and information to gather, how to analyze the information and data that we gathered and other methodologies which we can use. The information which we gather depends on our research questions. If question is clear then information will be clear to us and we can gather the data related to our research question. After gathering the data next step is to analyze the data. In which correlational question required to make correlations, theoretical evaluation required evaluation of entire theory and Cost Benefit analysis of policies required a method to conduct a cost benefit analysis. Next step is to select the methodology. Think about practical and intellectual considerations when deciding which methodologies to employ. Having a clear methodology is often important, especially in the sciences.

Methodology can be used to achieve the perfect results from research project. Basically methodology is a step wise process which starts from planning, moves toward implementing and then analysis. Present study is based on the impact of operational risk in banking industry. The research is based on descriptive as well as empirical in nature. I collect the data from descriptive method from 15 Pakistan commercial and Islamic banks, registered in Central bank and then apply empirical methods on it to get satisfactory result. In study descriptive research regression and correlation to get the accurate information and desired result. Descriptive research is the type of research questions, research design and data analysis that are used to a given topic.

Descriptive statistic related with findings out "what is" applied to investigate the stated question. Descriptive study is a mean to understand the question and what methods can be used to get the answer of our research question; it does not give the answer of our question. 
Descriptive study is based on summary data, measure of central tendency, mean median, mode, percentage, deviance from mean, correlation between variables and variation.

Correlation is the strength of relationship, measured linearly between two variables is called the correlation. When the values of high variables are linked with the value of the other high variable then it is call positive correlation. When the values of high variables are linked with the value of low variable then it is called negative correlation. Correlation varies from -1 to +1 . The values which are close to -1 , then it will indicate the high degree of negative correlation and if values are close to +1 then it will show the high degree of positive correlation 0 indicates no correlation and values close to zero express poor correlation.

A statistician Francis Galton was coined the historical meaning of term regression. Regression is use to show the relationship between two or more variables and to where a change in one variable link with the change in one or more independent variables. It is a statistical method which is used to estimate the relationship between two variables. Regression is used for future forecasting and prediction. The hypotheses of study are as follows;

Hypothesis I: Bank operational risk has an impact on financial performance.

Hypothesis II: Bank operational risk has an impact on the gearing ratio.

Hypothesis III: Bank operational risk affects the capital ratio of the banking industry.

Hypotheses IV: Bank operational risk has an effective impact on the spread ratio of the banks.

\section{A. Data \& Sample Selection}

Data collection is a process in which data is collect and then prepare for more improvements in a similar project. The purpose to collect data is to obtain the information to keep in record and to make decision about critical issues. Data is collected to provide the information related to a specific topic.

To determine the impact of operational risk in banking industry, collection of data from 15 banks including conventional and Islamic banks such as; National Banks of Pakistan, The Bank of Kyhber, The Bank of Punjab, Al Baraks Bank Pakistan Limited, Allied Bank Limited, Askari Banak Limited, Bank Al-Habib Limited, Bank Al-falah Limited, Bank Islami Pakistan Limited, Dubai Islamic Bank Pakistan Limited, Faysal Bank Limited, Habib Bank Limited, MCB Bank Limited, Meezan Bank Limited, Standard Chartered Bank Limited. Selection of previous data of above mentioned banks for the years of 2007-2011. Main source of data collection is financial reports of these 15 selected banks and annual reports of the State Bank of Pakistan. Financial items from the balance sheet and income statement are 
taken of selected banks. Collection of data is reliable because it was purified twice by sources. There are very minor chance of errors and mistakes. The primary data which is theoretical side is based on articles, books, e-articles, and websites that are related to the subject of current study. Secondary side is practical side which is based on financial reports and operational data of the sample banks for period 2007-2011.

\section{B. Variables definition}

In research, different variables are used which are dependent and independent. In my research, I selected the variables due to which I can judge the impact of operational risk on banking industry. In this study the dependent variable is Return on Equity (ROE) and independent variables are Return on Asset (ROA). Asset Management (AM), Spread Ratio (SR). Debt/Equity Ratio (DER), Capital Ratio (CR).

\section{Dependent Variable: Return on Equity}

It is used to measure the rate of return on the shareholders equity. It measures the efficiency of firm which generates from every unit of shareholder's equity. ROE from $15 \%$ to $20 \%$ are generally considered good. It shows percentage profit generation on investments. Similarly, Bizuayehu (2015) also have taken ROE as dependent.

$$
\text { Return on Equity }(R O E)=\frac{\text { Annual Net Income }}{\text { Average shareholder's equity }}
$$

\section{Dependent Variable: Return on Asset}

The return on asset (ROA) shows how a firm's assets are profitable for generating revenue. Return on asset is used to judge that hoe efficiently a firm is using assets of the firm to generate profit. It must be displayed in percentage. The formula used to calculate the return on asset it. Likewise, Lyambiko (2015) used ROA as dependent variable to measuring financial performance of banks.

$$
\text { Return on Assets }(R O A)=\frac{\text { Net Income }}{\text { Average Total Assets }}
$$

\section{Independent Variables: Debt/Equity ratio}

A ratio which is used to measure the financial leverage calculates by dividing total liabilities by its stockholder's equity. It indicates the proportion of debt and equity which the company is used to finance its assets. Oluwafemi, Akeke, Simeon and Olawale (2014) have used ROA in their study as an independent variable.

$$
\text { Debt/Equity ratio }=\frac{\text { Total Liabilities }}{\text { Total Assets }}
$$




\section{Independent Variables: Spread Ratio}

Spread ratio is a strategy in options trading which involves buying of some number of options and selling of other option of the same underlying market on different strike price and same expiration date.

\section{Independent Variables: Asset Management}

Asset management means to manage thy physical assets of the company in which selection of assets, maintenance of assets; inspection and renewal of assets are included. It plays a vital role in analyzing operational performance of the company. It is also used to determine the profitability of the company that utilizes the assets for enhancing their business. Asset management is calculated by using following terms:

$$
\text { Asset Management }=\frac{\text { Operating Income }}{\text { Total Assets }}
$$

\section{Independent Variables: Capital Ratio}

The ratio which shows the percentage of equity in total assets of the company is called capital ratio. It is the ratio of between shareholder's equity and total assets of the firm.

$$
\text { Capital Ratio }=\frac{\text { Total Share Holder Equity } \quad \text { X } 100}{\text { Total Assets }}
$$

\section{Empirical Results and Discussion}

I have selected 15 banks which some are Islamic banks and some are Conventional banks. Islamic banks are and conventional banks are. This study is based on the impact of operational risk on the banking industry in which all departments of banks are included. I have taken the past 5 years $(2005,2007,2008,2009.2010,2011)$ data of 15 banks. The results of descriptive analysis are shown below in table.

Table 1: Descriptive Statistics

\begin{tabular}{|l|c|c|c|c|c|c|}
\hline & AM & CR & DER & ROA & ROE & SR \\
\hline Mean & 0.0882 & 0.0923 & 0.7893 & 0.0072 & 0.0524 & 8.0243 \\
\hline Median & 0.1028 & 0.0744 & 0.8723 & 0.0108 & 0.1000 & 0.4350 \\
\hline Maximum & 0.4098 & 0.3145 & 0.9842 & 0.0372 & 0.3400 & 572.0590 \\
\hline Minimum & -0.2602 & -0.0310 & 0.0856 & -0.5410 & -1.9900 & -0.0321 \\
\hline Standard Deviation & 0.1004 & 0.0643 & 0.2440 & 0.0156 & 0.3684 & 66.0149 \\
\hline Skewness & -0.5537 & 1.0323 & -1.9977 & -1.6739 & -4.6522 & 8.4859 \\
\hline Kurtosis & 6.2661 & 4.3931 & 5.7022 & 7.7857 & 26.0126 & 73.0125 \\
\hline Jarque-Bera & 37.1607 & 19.3883 & 72.7063 & 106.6005 & 1925.4860 & 16218.12 \\
\hline Probability & 0.0000 & 0.0000 & 0.0000 & 0.0000 & 0.0000 & 0.0000 \\
\hline
\end{tabular}


The above tables are showing the descriptive results of all variables. The dependent variable is ROE, Which has positive value of mean that is 0.0524 . The table is showing the positive mean value of independent variables which are asset management, Capital Ratio, Debt/Equity Ratio, Return on assets and Spread Ratio. The standard deviation of ROE is 0.368444 which shows that return on per unit equity is satisfactory, the maximum value of $\mathrm{ROE}$ is 0.34 and minimum value is -1.99 . In dependents variables, ROA has Maximum value 0.0372 and minimum value -0.541 , DER has maximum value 0.944245 and minimum value 0.8563 , SR has maximum value 572.1059 and minimum value -0.0321 , CR has maximum value 0.3145 and minimum value -0.031 , AM has 0.409883 and minimum value -0.260262 , $\mathrm{SD}$ is also mentioned in the table 1 . The size of firm is different and every bank has its own strategies to overcome the operational risk so the values are also varying from each other. Relationship between dependent and independent variables are also calculated through regression and correlation model which is shown in table 2 and 3 respectively.

Table 2: Correlation Matrix

\begin{tabular}{|c|c|c|c|c|}
\hline & AM & DER & SR & CR \\
\hline AM & 1 & - & - & - \\
\hline DER & -0.05537 & 1 & & \\
\hline SR & 0.108917 & 0.055896 & 1 & \\
\hline CR & 0.104055 & 0.117922 & -0.00821 & 1 \\
\hline
\end{tabular}

Correlation Matrix is showing the relationship between the variables which is calculated in above stated table 2. The table is showing that there is less relationship between the independent variables. Only DER and SR have the sufficient date correlation. DER is showing the negative relation towards AM, CR, and SR have a positive date correlation SR has positive correlation with AM and DER. Similarly there is a positive correlation of CR with AM and DER, negative correlation with SR. There is no well-built relationship between the independent variable in the matrix.

Table 3: Dependent Variable

\begin{tabular}{|c|c|c|}
\hline Variable & Coefficient & t-Statistic \\
\hline Constant & -0.37955 & -4.418816 \\
\hline SR & -0.00028 & -0.872238 \\
\hline AM & 0.809594 & 3.533443 \\
\hline R-Squared & 0.781137 & \\
\hline F-statistic & 49.25307 & \\
\hline
\end{tabular}


Pakistan Journal of Humanities and Social Sciences, 6(1), 2018

Table 3 is showing the coefficient and t-statistics which I obtained from application of fixed model, using ROE as the dependent variable. Spread Ratio has insignificant impact on the ROE and shows negative relation in the table. Capital is the most significant part of the firm. In above stated table $\mathrm{CR}$ has positive relation with the ROE. Table shows that operational risk has a minor impact on the working of the firm's capital which is controllable. The R-squared value is 0.781137 which approves that independent variables model explained the $78 \%$ variation of dependent variable. The remaining $22 \%$ is not explained. The value of Fstatistic which is mentioned in the table shows the model's stability and strength towards the study.

\section{Conclusion and Recommendations}

Now these days, it is recognize that the operational risk is the risk which has highly contribution toward the losses of financial institutions. Banks applied different techniques which are beneficial for mangers to measure and manage the risk related to the operations of banks. In different banks quantity and quality to manage the risk is different. In last year, all financial institutions covered credit and market risk and proper acknowledgment about operational risk did not exist. Due to increase in complexity and size of banks the ratio of loss also expand, operational managers started to focus on the operational risk. They started to introduce different approaches which try to overcome the operational risk. Corporate governance and accounting standards are introduce to minimize the operational risk, which stresses on the effective organizational control and transparency in accounting methods. The auditors are also appointed to encourage the disclosure of improved operational risk management procedure. Existing study is based on the impact of operational risk on banks practices from year 2007 to 2011.

By analyzing the annual reports of 15 banks, I am providing the evidence that operational risk have a significant impact on the operations of banks. From the period of 1998 the practices towards disclosure of operational risk were started to improve. During the period of 2007 to 2011, the awareness regarding the management of operational risk was very much improved. But in certain department of the banks operational risk exists to high extent Banks deals in money so there are highly chances or risk. The operational risk in banking industry affects the many internal and external activities. I focused on the internal factors of the banks which are affected by the operational risk. The activities related to the operational risk management are different for different banks. 
The improvement in governance and transparency in information which is related to risk must be applied. There should be applied improved practices regarding the management of operational risk. It is also very important that the data and ideas must be exchange and an opportunity should be provided to firm's individuals to get more knowledge about risk and how it is possible to deal with the risk. The studies which are dealing with the operational risk in financial institutions are limited. Some studies have explained that reputational risks in all banks which are cause of operational losses are the result of weak disclosure practices of banks management towards operational risk. From this study it is analysis that operational risk has large impact on the banking profitability and different operations of banks. Banking of modern age has implemented many techniques to overcome the impact of risk on their operations.

\section{A. Limitations of the Study}

The study discussed about internal factors of the banks which the affected by the operational risk. There are many other internal factors which I can discuss but due to shortage of time I was not able to focus on them. There are also many banks which are working on the practices of operational risk and try to overcome them. But due to time limitations I could not able to consider them. 
Pakistan Journal of Humanities and Social Sciences, 6(1), 2018

\section{References}

Abdullah, A., Khan, A. Q., \& Nazir, N. (2012). A comparative study of credit risk management: a Case study of domestic and foreign banks in Pakistan. Academic Research International, 3(1), 371

Acharyya, M. (2008). In measuring the benefits of enterprise risk management in insurance: An integration of economic value added and balanced score card approaches. ERM Monograph, 1-25.

Adeusi, S. O., Akeke, N. I., Adebisi, O. S., \& Oladunjoye, O. (2014). Risk management and financial performance of banks in Nigeria. Risk Management, 6(31).

Bizuayehu, M. (2015). The impact of Credit Risk on financial Performance of Banks in Ethiopia.

Channar, Z. A., Abbasi, P., \& Maheshwari, M. B. (2015). Risk Management: A Tool for Enhancing Organizational Performance.Pakistan Business Review, 17(1), 1-20

Fernández Laviada, A., Martinez Garcia, F. J., \& Somohano, F. M. (2005). Operational Risk Management under Basel II: The Case of the Spanish Financial Services.

Ferreira, S. J., Viljoen, D., \& van Vuuren, G. (2016). The Effect of Operational Loss Events On The Reputation of South African Banks.

Helbok, G., \& Wagner, C. (2006). Determinants of operational risk reporting in the banking Hussain, M. S., \& Shafi, M. (2014). Operational risk in Banks: A Review.

Hussain, A., Ihsan, A., \& Hussain, J. (2016). Risk Management and Bank Performance in Pakistan.

Izhar, H. (2011). Identifying operational risk exposures in Islamic banking.

Jobst, A. A. (2007). It's all in the data-consistent operational risk measurement and regulation. Journal of Financial Regulation and Compliance, 15(4), 423-449

Jobst, A. A. (2007). The treatment of operational risk under the New Basel framework: Critical issues. Journal of Banking Regulation, 8(4), 316-352.

Khan, T., \& Ahmed, H. (2001). Risk management: an analysis of issues in Islamic financial industry. Islamic Development Bank, Islamic Research and Training Institute industry.

Lewis, N. D. C. (2004). Operational Risk with Excel and VBA: Applied Statistical Methods for Risk Management, + Website (Vol. 244). John Wiley \& Sons. 
Lyambiko, M. R. (2015). The Effect Of Operational Risk Management Practices on the Financial Performance In Commercial Banks In Tanzania (Doctoral Dissertation, School Of Business, University Of Nairobi).

Mehra, Y. S. (2012). Operational Risk Management in Indian Banks: Issues and Challenges. Indian Journal of Economics and Business, 11(1).

Medova, E. A. (2001). Operational risk capital allocation and integration of risks. Research Papers In Management Studies-University Of Cambridge Judge Institute of Management Studies Wp.

Mehra, Y. S. (2011). Operational risk management in Indian Banks: impact of ownership and size on range of practices for implementation of advanced measurement approach. In Money and Finance Conference. February (pp. 25-26).

Na, H. S., Miranda, L., Van den Berg, J., \& Leipoldt, M. (2006). Data scaling for operational risk modelling.

Sundmacher, M. (2004). Operational risk capital charges for banks: consideration and consequences.

Sundmacher, M. (2006). Consistency of risk reporting in financial services firms.

Shafiq, A., \& Nasr, M. (2010). Risk management practices followed by the commercial banks in Pakistan. International Review of Business Research Papers, 6(2), 308-325.

Sturm, P. (2013). Operational and reputational risk in the European banking industry: the market reaction to operational events, Journal of Economic Behavior \& Organization, Vol. 85, (2013): pp.191-206.

Sweeting, P. (2011). Financial Enterprise Risk Management, New York: Cambridge University Press. 